\title{
Asia's nuclear family
}

\author{
If North Korea has nuclear weapons, its neighbours may want to develop \\ their own. Geoff Brumfiel and David Cyranoski ask whether Japanese \\ and South Korean scientists would answer a call to nuclear arms.
}

$\mathrm{H}$ irotaka Sugawara has an unlikely proposal. One of Japan's most prominent high-energy physicists, he has spent his working life studying sub-atomic particles. Now a visiting researcher at the University of Hawaii, Sugawara wants to use a beam of one such particle - the ghost-like neutrino, which passes through most matter - to root out and destroy stocks of hidden nuclear weapons. "It's rather futuristic," he admits.

Sugawara says the beam will interact with any plutonium it encounters, melting or even igniting the weapon. The proposal may never be tested, but the fact that Sugawara felt the need to suggest building a device that could detonate an enemy state's nuclear weapons shows how concern over nuclear proliferation is affecting researchers in Japan.

Sugawara doesn't mention a nation on which he would use the beam, but North Korea is one obvious target. The country could develop, or may already have developed, a nuclear device. This could leave many scientists in Southeast Asia facing an unwelcome decision: knowing that a feared and unpredictable neighbour is developing a frightening military advantage, should they support nuclear-weapons programmes in their own countries, or resist such proliferation?

North Korea hit the headlines last month, when its officials claimed to have developed nuclear weapons, but tension in the region has been high since late last year. Under a 1994 agreement, the country halted development of its nuclear arsenal in exchange for funding from the United States, Japan and South Korea for energy projects. The deal remained intact until last October, when the United States announced it had evidence that North Korea had gained new nuclear-weapons technology.

Since then, North Korea has appeared determined to let the world know of its nuclear plans. In December, it kicked out the inspectors monitoring its mothballed nuclear plants. A month later, it pulled out of the Nuclear Non-Proliferation Treaty and, a month after that, restarted its nuclear facilities. And in February and March this year, it test-fired two unarmed missiles into the Sea of Japan.

North Korea has since said that it does indeed have nuclear weapons, but has also proposed a deal to end its nuclear programme if the United States pledged not to attack. Given North Korea's history of deliberate obfuscation, observers warn against reading too much into either statement.

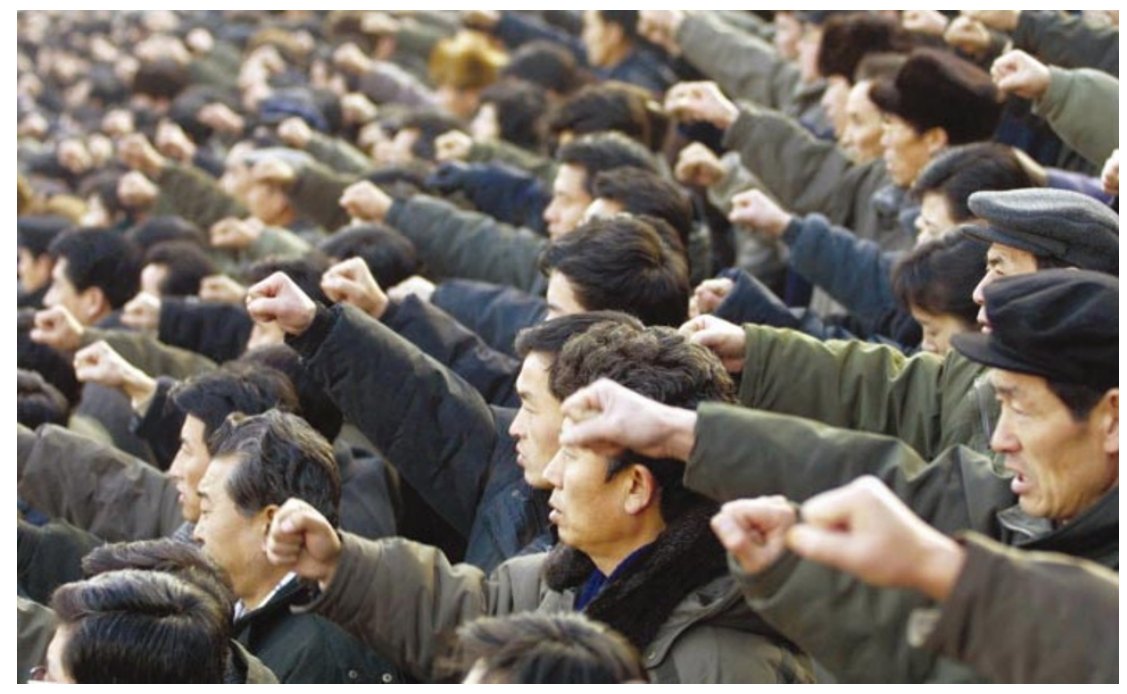

Arms race: many fiercely ideological North Koreans see nuclear weapons as vital for their nation.

Experts agree, however, that North Korea has the potential to back up its sabre-rattling. A hundred kilometres north of the capital Pyongyang, the town of Yongbyon is home to a 5-megawatt nuclear reactor and a plant for reprocessing its spent fuel. The reactor runs on uranium, producing waste from which the reprocessing plant can extract plutonium which could then be used in a nuclear weapon.

\section{True believers}

Only a handful of outside scientists and technical experts have been to Yongbyon. Robert Alvarez, an expert in nuclear programmes at the Institute for Policy Studies in Washington DC, visited in 1994 and 1995 with teams from the US Department of Energy. He estimates that a few hundred researchers work there - most trained at Soviet institutions, although the younger ones studied at Pyongyang's Kim Il Sung University. They are passionate followers of North Korea's philosophy of independence from foreign powers, and believe nuclear weapons will ensure their nation's security. "This is their life's work," says Alvarez. "These guys are fiercely dedicated."

Their dedication has endured in harsh and dangerous working conditions. Alvarez recalls lecture rooms that lacked heat and electricity. What's more, the nuclear facilities at Yongbyon are based on early British and US designs, published in the open literature, which are now generally considered unsafe and unreliable.

The reactor is an early version of a 'Magnox' facility, the first of which was opened at Calder Hall in Cumbria, northwest England, in 1956. Improved versions are still used in Britain, but the original plants are considered unreliable because the uranium fuel rods' casings made from the magnesium alloy that gives the design its name — can crack, destabilizing the reactor. And the North Korean device, says Alvarez, is a replica of the Calder Hall reactor down to the last vacuum tube.

The US-designed reprocessing plant is similarly unreliable. Unlike modern versions, the plant requires chemicals to be mixed manually, increasing the chances of spills and leaks. And Alvarez describes the pool where spent fuel is kept as a "radioactive soup". He says that the protective cladding surrounding the spent fuel rods has been compromised, and that the pool water is dangerously radioactive. Uranium in the rods could potentially react with air and ignite.

Despite this apparent decrepitude, the US Central Intelligence Agency estimates that Yongbyon produced 8-16 kilograms of plutonium before it was shut down enough for at least two weapons. More could be added if the reprocessing facility is reactivated, although Alvarez points out that its materials have been stagnating since 1994. "Think about having your car sitting for that long," he says. "It isn't likely that they can just turn the key and everything will work."

If North Korea has used its plutonium to build a weapon, it is unclear what it intends 
to do with it. Retired physicist Richard Garwin, who worked on US nuclear-weapons programmes and was part of a 1998 US commission that assessed the missile capabilities of several countries, thinks that the country may plan to sell nuclear weapons, as it already exports ballistic missiles. Others argue that the nuclear programme is just a tool for negotiating with the United States. "There are only a few people in North Korea Mitchell Reiss, dean of international affairs at the College of William and Mary in Williamsburg, Virginia, who headed the body charged with implementing aspects of the 1994 agreement.

Whatever the reason, Garwin and others agree that Japan and South Korea could feel pressured to develop their own nuclear weapons if North Korea does so. Both countries have the resources to build them - Japan, for example, has up to eight tonnes of plutonium within its borders. Japanese officials say that the fuel is to be used in nuclear power plants - but it could also be used to make a weapon. And although South Korea has signed a deal with the United States saying that it will not produce weapons-grade nuclear material, it does have the resources to develop such weapons should it choose to do so.

\section{Scientific stance}

If South Korea and Japan decide to initiate nuclear-weapons programmes, how will their physicists and engineers respond? The attitude of these groups is clearly important. On a practical level, the development of nuclear weapons is impossible without skilled scientists. Garwin points out that in the case of Pakistan and India's nuclearweapons programmes, which were established in the 1970s, it was the scientists who pushed the technology, while the military was initially uninterested.

On the surface, Japanese and South Korean scientists seem to be opposed to nuclear weapons. The 8,000-member Atomic Energy Society of Japan has pledged not to develop them, mirroring the country's constitutional principle never to develop, hold or use nuclear weapons. "The peaceful use of nuclear energy who know why they're doing this," concludes

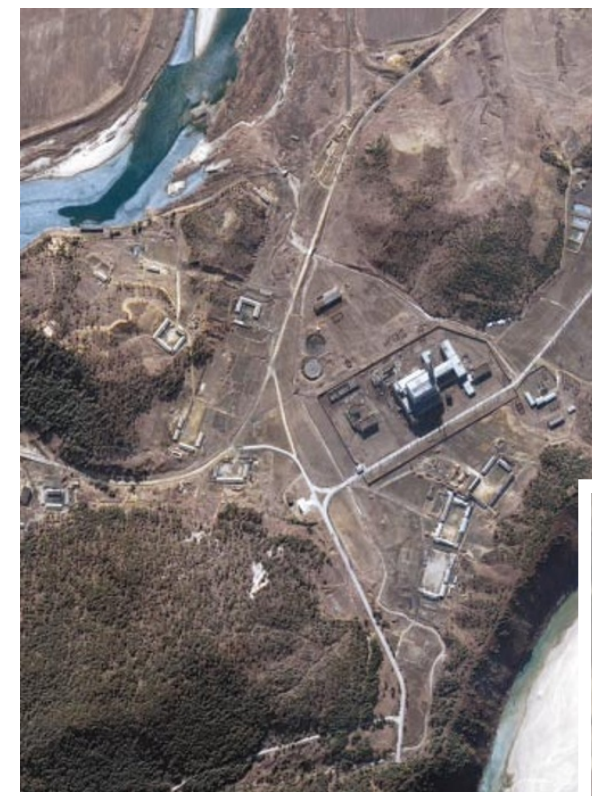

A plume of smoke (circled, inset) rising from the Yongbyon nuclear reactor supports suspicions that the complex (main picture) is active again.

has been etched into the Japanese DNA over the past half-century," says Tetsuo Sawada, a nuclear engineer at the Tokyo Institute of Technology. Jungmin Kang, a nuclear engineer who is now a Seoul-based associate of the Nautilus Institute, a security and sustainability think-tank in Berkeley, California, says that South Korean scientists are similarly resistant to nuclear weapons.

But a closer inspection reveals that these attitudes may result from the reluctance of scientists in the region to become involved in politics, rather than a fundamental objection to nuclear weapons. Over the past few years, Tatsujiro Suzuki, an expert in atomic-energy policy at Keio University in Tokyo, has been trying to get nuclear scientists to sign a 'peace pledge', in which they vow never to work on nuclear weapons. By this January, just 110 Japanese researchers had signed.

Those who declined to sign won't say publicly why they did so. A reluctance to declare personal politics may be part of the reason. "Many say that taking an individual stand is

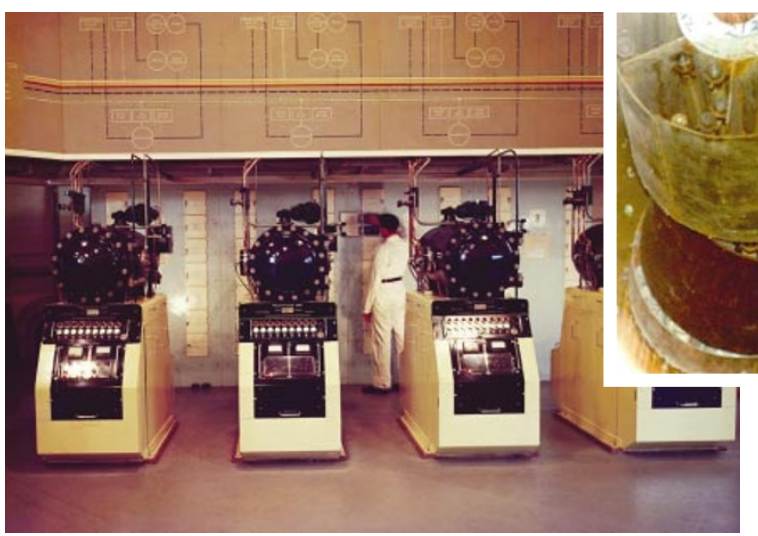

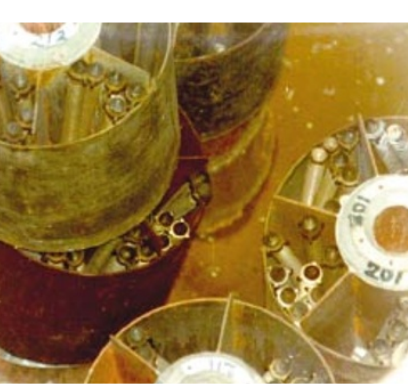

North Korea's nuclear reactors use 1950s technology (left); its stores of spent fuel (above) have been called "radioactive soup".

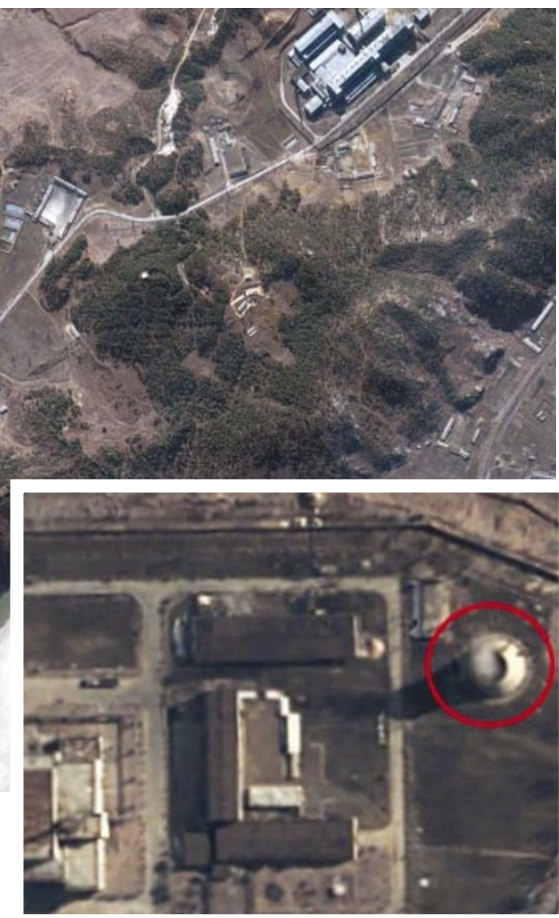

not part of Japanese culture," says Suzuki. But others may be refusing the pledge because they want to leave the door to nuclear weapons open. "Some good friends said they wouldn't sign because they thought they might be asked to work on nuclear weapons in the future," says Suzuki. And when he polled his students, 30\% said that their country should eventually develop nuclear weapons. It seems that resistance to nuclear weapons among Japanese scientists may not run very deep.

Suzuki has also had problems in persuading South Koreans to sign his pledge. Kang says that there is little chance of South Korea developing nuclear weapons in response to activities in the North. But if Japan reveals nuclear ambitions, things could change. "I am sure that South Korea will try to develop nuclear weapons if Japan does so," he says. This attitude is reflected in the words of those South Koreans who refused to sign Suzuki's pledge, many of whom cited Japan's plutonium stocks as a reason for not ruling out nuclear weapons.

Such evidence is only anecdotal, but it suggests that if the political leaders of Japan and South Korea want to develop nuclear weapons, they will find scientists willing to help them do so. While North Korea keeps it intentions shrouded in a diplomatic fog, the likelihood of this occurring is unclear. But if the country does push ahead with its plans, those who seek to prevent nuclear proliferation may have to look beyond the scientific communities of neighbouring nations for support.

David Cyranoski is Nature's Asian-Pacific correspondent. Geoff Brumfiel is Nature's Washington physical sciences correspondent.

Suzuki's peace pledge

www.peacepledge.gr.jp 